\title{
Semester students' perceptions about online class during COVID-19 pandemic
}

\author{
Bhan Singh Dhami \\ M.Ed. Fourth Semester (English), Kailali Multiple Campus, Dhangadhi
}

\begin{abstract}
Face-to-face delivery of education system had been greatly affected due to the outbreak of COVID-19. As an alternative to it, classes were run online wherever there was access to the Internet with technological devices. With this scenario, this study explored the perceptions of semester students about online class at master's level during COVID-19 pandemic. By using the phenomenological research design of qualitative study, purposive sampling technique was used to collect the views of three students of master's level studying at third and fourth semesters at an affiliated campus of Tribhuvan University (TU) and a constituent campus under Far Western University (FWU) of Nepal. Semi-structured online interview was conducted to collect the data. The result showed that the students were positive towards online delivery mode due to the need for getting education during COVID-19 pandemic.
\end{abstract}

Keywords: Perception, online class, semester system, COVID-19, pandemic

\section{Introduction}

Learning through online class is new for many students in the context of Nepal. In semester system, students' attendance is important. Online class has become inevitable in this sort of critical situation in the field of education. In this technological era, teaching and learning process should be internet based by which the teachers can teach their students from their own home and the learners can learn staying at their home. Information and Communication Technology (ICT) has brought alternative opportunity for gaining knowledge without wandering colleges and universities in the context of Nepal.

At the end of 2019, Corona Virus Disease 2019 (COVID-19) first outbroke in Wuhan, China and with the beginning of 2020, it rapidly spread all parts of the world. Due to its widespread nature, World Health Organization (WHO) declared it a fatal pandemic. WHO suggested people to maintain physical distancing with the total avoidance of social gathering. WHO continued to convey the message of how people combat with the virus. As it is said that health is wealth, many nations declared lockdown to save their people from the virus. Almost all sectors were shut down 
including academic sector. Nepal also declared lockdown and all sectors were largely affected due to COVID-19 crisis.

In academic sector, the alternative way of teaching and learning was sought. Dhami (2020) highlights that virtual classes can be conducted to continue teaching and learning during the time of the lockdown in this crisis of global pandemic. Using and utilizing ICT tools, the conduction of classes become essential for the completion of course and for the involvement of learners in their study.

According to Ali (2020, p. 16), "In light of the rising concerns about the spread of COVID19 and calls to contain the Corona Virus, a growing number of tertiary institutions have shut down in regards to face-to-face classes globally." In this critical situation, no academic institutions could conduct physical classes. Online learning has appeared one of the best alternatives of learning throughout the world. Therefore, this study sought semester system students' perceptions about online classes.

Universities started online classes mostly after COVID-19 crisis. Campuses and colleges under different universities of Nepal conducted the online classes through Microsoft Teams, Google Meet and Zoom Meeting. Students also had to join online classes. Since online mode of instruction was new for students in Nepal, semester students' perception about online classes in the context of Nepal was the gap in the existing literature. With this view, the purpose of this study was to explore how semester students perceived online classes during the COVID-19 crisis. In this connection, this study tried to explore the semester students' perceptions about online classes, identifying the significance of online class learning in the context of Nepal.

To get content and context knowledge related to any subject matter during the crisis and onwards, online class seems to be significant. The students of university level in particular and school and college level in general are benefitted from this study. Moreover, the novice teachers of different levels can also get the ideas and information about the significance of ICT to conduct online classes so that they can facilitate their students in learning even in the critical situation of crisis like COVID19. This study is equally beneficial to adult learners who want to restart their study in relevant subject of their interest despite the fact that they are busy in their profession.

\section{Research Questions}

To meet the objectives of my study, this study aimed to answer the following research questions:

1. How do the semester students perceive online classes during the COVID-19 crisis?

2. Why do they think online classes are significant in the context of Nepal? 


\section{Literature Review}

This study reviewed ICT policy and some of the ICT programmes related to this research study such as ICT National Policy-2015, ICT Master Plan (20132017), National Curriculum Framework (2006 \& 2019), School Sector Development Plan (2016-2023) and Student Learning Supportive Directive (2020) as supportive theories of this study.

To improve students' outcomes and results, ICT National Policy-2015 focuses on e-learning, e-education and e-library especially at university level teaching and learning. ICT can be used to facilitate teaching and learning. But there is not strict provision of the use of ICT in education. Likewise, ICT Master Plan (2013-2017) has taken ICT as an important tool for teaching and learning which helps to reduce the digital gap to maintain balance in the digital literacy. The ICT programmes such as computer engineering, computer science at Bachelor and Master's level courses are included to produce skilled manpower in the field of ICT.

Similarly, National Curriculum Framework (2019) has taken ICT as an important tool to promote education. ICT has been included in the curriculum so that the learners get the reality of global education. It has also defined ICT as both means and tool for learning which is being established as a tool to enhance personal, institutional, educational and economic development. Moreover, it clearly states that ICT should be taken as a subject and means in school education though teaching and learning materials of all subjects related to different levels, and classes have not digitalized yet. However, for the use of ICT, the creation of favourable environment related to physical aspect is challenging. School Sector Development Plan (20162023) has set the goals to enhance the ICT skills in students for the improvement of teaching and learning.

Likewise, Student Learning Supportive Directive (2020) has been published as a supportive guide to conduct teaching learning process during the COVID-19 pandemic. It has provided different options for the students. As their access to any means of communication technology, students can continue their learning. Those students who have access of the radio, television and computer with the Internet access can learn by utilizing those means of ICT.

However, the implementation of plans is important so that teachers and learners could be benefitted from the use of ICT. Training on ICT has become essential to conduct online class at university level in particular and at school level in general. Teaching learning can be effective by using different devices such as mobile 
phones, laptops, etc. with the Internet access so that students can be independent to learn and interact with their instructors and other students (Singh \& Thurman, 2019). Similarly, in the words of Dhawan (2020, pp. 6-7) "Online learning can be termed as a tool that can make the teaching-learning process more student-centred, more innovative, and even more flexible." Online learning is a tool to foster learning so that the teaching and learning process becomes student centred.

Similarly, most of the terms such as online learning, open learning, webbased learning, computer-mediated learning, blended learning, m-learning, etc. need Internet that offers the possibility to learn from anywhere, anytime, in any rhythm, with any means (Cojocariu, Lazar, Nedeff, \& Lazar, 2014). Instead of physical classes, online classes help to break the chain of corona virus during this global crisis. Learning and living both can be continued through online classes, but it cannot be predicted the secured life in physical classes during the critical period of COVID19 crisis.

Likewise, Rapanta, Botturi, Goodyear, Guàrdia and Koole (2020, p. 942) opine, "For higher education institutions around the world to be competitive (again), evidence of faculty preparedness in terms of professionalism is necessary. Online teaching is an essential part of such professional preparedness but not the only one." Knowledge and practice regarding online class seems essential for both teachers and students. Furthermore, Mishra, Gupta and Shree (2020) state that teachers could get regular feedback from their students about the online teaching. Similarly, Agarwal and Kaushik (2020) concur that online teaching is not expensive and must be made a part of the postgraduate training after lockdown in the case of India. According to Jena (2020, p. 91), "Online Learning is the most common method of distance learning today. During the lockdown period for Covid-19, online learning is the best platform to keep learners/educators engaged and safe by maintaining social distancing." Therefore, online learning can be taken as reliable learning during the time of critical situation.

Thapa (2020) argues that the face-to-face teaching-learning system is highly dominant in Nepali education setting. He further states that developed countries have minimum ICT infrastructure and distance learning has been officially recognised in those countries. He highlights that TU and Kathmandu University (KU) and Nepal Open University (NOU) have been offering a wide range of online courses. Parajuli (2020) contends ICT has drawn the attention of stakeholders to grow the use of technological tools in the post-COVID-19 era in Nepal by opening several 
possibilities. Furthermore, he asserts that the use of ICT tools for teaching and learning through online mode has become an alternative mode instead of traditional face-to-face mode to prevent the spread of corona virus.

Although there has been a wide body of literature related to online teaching issues during COVID-19 crisis, this study is different in that it seeks the perceptions of the master's level semester students about online teaching and learning. This issue is quite new for them in that they have never experienced such mode of instruction before. COVID-19 pandemic made the teachers and learners do online for the continuation of education at higher level.

\section{Methods and Procedures}

\section{Research design}

This study employed a phenomenological research design of qualitative method to explore the experiences of the semester students about the online delivery of instruction in higher education in Nepal in general and at master's level in particular. This qualitative research attempted to explore perceptions of semester students about online classes for the continuity of teaching and learning process during COVID-19 crisis in the context of Nepal.

\section{Participants}

The participants of the study consisted of three master's level learners of an affiliated campus of Tribhuvan University (TU) and a constituent campus of Far Western University (FWU) located in Kailali district. The participant studying at FWU is mentioned as Rajanish, whereas Asha and Tank belonged to TU. Realizing the ethical privacy, pseudonyms are used for the participants of this study. After lockdown due to COVID-19 pandemic, they were taking online classes. The participants were informed before, after and during the research process about the aims of the research. The participants were affirmed to be volunteers and by using purposive sampling technique, they were selected for this study.

Rajanish is one of the participants in this study who is originally from Bajhang district and permanently lives in Kailali district. He has been studying at third semester in a constituent campus of FWU. His major subject is English. He is 30 years old. He is learning through online and for Internet connectivity, he bought WiFi at his home. He had almost five months experience of learning of online class. 
Asha is from Darchula district and temporarily lives in a rented house in Kailali. She has been studying at 4th semester at an affiliated campus of TU which is in Kailali district. Her major subject is also English. She has an android cell phone and a laptop to take online class. Using Internet data, she has been learning English. She had five months experience about learning through online class.

Tank is from Doti district and temporarily lives in Kailali. He is studying Nepali as a major subject at an affiliated campus of TU that is located in Kailali district. Due to COVID-19, leaving rented house he stays at his own home and is taking online classes regularly for five months. He uses Internet data to continue online learning.

\section{Research tools}

The information collection instrument consisted of background interview and semi structured in-depth interview from Zoom meeting where I interviewed the participants by conducting one meeting for one participant. The background interview covered the questions about their name, experiences, and present level of study. Mainly in third time settings, interviews were conducted by including research questions relevant to this study. The participants were asked to express their perceptions about online classes for the continuation of learning process during and after the COVID-19 crisis. Thus, the information was gathered through the semistructured in-depth interview technique.

\section{Procedure}

This study employed a two-step procedure: the first was information collection and the second was information analysis. In the information collection, the participants were asked to express their perceptions and experiences about online classes to boost learning process during the period of COVID-19 crisis in the context of Nepal. And the second involved the information analysis procedure through thematic analysis.

\section{Results and Discussion}

After analyzing the data collected from the three university level learners, the following themes were drawn for this section of the study: online class as semester system supportive class, online class as technological awareness raising class and online class as home delivery class. 


\section{Online class as semester system supportive class}

ICT based teaching is conducted in semester system class. The teachers teach using power point presentation. They have laptops in which they prepare power point slides to teach the students applying technology in the process of imparting education.

Students are also guided to use ICT tools so that they can be aware in the use of technology in the process of learning. Due to COVID-19, online classes have been conducted by universities to complete the courses. In the words of Dhawan (2020,p. 7), "The Corona Virus has made institutions to go from offline mode to online mode of pedagogy." Online learning has become more significant during the pandemic.

Likewise, Nepal's (2020) view is that virtual classes are considered as the best options for bridging the learning gap seen in COVID-19 pandemic. In this terror and horror situation of corona virus, learning through online class seems very supportive. According to Pal and Vanijja (2020, p. 1), "Globally, the teachinglearning process is evolving rapidly from a traditional classroom environment to a mixture of traditional plus online learning." The global pandemic has brought worldwide crisis in most sectors including education. When I asked, "What is your perception about online class?” Rajanish told (wearing a blue coloured mask):

Yes, sound health is essential to conduct learning. Ok, let me start my first time experience of taking online class. During lockdown, I focused myself in self study. My campus started online classes in June. It's my first experience of online learning. As my teachers taught using power point presentation in formal physical class, I found similarity in online learning. I got the idea of using ICT in learning. I had internet facility at home ... so I like online learning where I learnt how to join and conduct meeting in Zoom and Microsoft teams.

Rajanish's experience is similar to Mishra's (2020) own experiences of taking online classes during COVID-19 pandemic that allowed him to be familiar with new technological tools in language learning. Actually, online class is emerging as one of the significant tools of teaching and learning in the context of Nepal.

Similarly, in response of the same question, Asha opines:

I perceive online class as fruitful one ... the supportive class in the semester system. Being an English learner, I like online learning but sometimes there was problem of network which created disturbance in learning. Really, the 
classes helped to complete the course. It has minimized the travelling cost, I mean bus fare or transportation cost. Clearly speaking online class has replaced travel cost. So, I think it is not costly.

Indeed, Asha's opinion is similar to Rana's (2020) view about the Internet based class which can be used as a means, but not as a replacement of physical classroom. Furthermore, Kapar (2020) states that online/virtual classes are taken as a complement to the physical classroom and an alternative during COVID-19 pandemic.

Responding the same question, Tank shares his experience of online learning as:

It is a great opportunity for me. I think online classes are complimentary of physical class. I used 'happy learning' data to learn from online which is not so expensive. I am also a Nepali subject teacher of a private school. I am applying the knowledge that I got from the online class of semester system in teaching Nepali subject to secondary level students. But physical classes are very important for developing socialization. However, in critical situation online learning is the best.

Tank's perception is similar to Poudel's (2020) argument that radical changes in educational system can't be expected because physical contact is equally important, not only for education, but also for living in human society. Moreover, Rana (2020) focuses on the utilization of the Internet facilities and the development of the mechanism of e-learning to complement social learning strategies. So, online class of semester system seems to be supportive class of that same system.

\section{Online class as technological awareness raising class}

Being 21st century as an era of technology, learners of this era should be familiar with the proper use of ICT to enhance learning. Learners should be individually aware about the innovative technology to get benefit from it. Sapkota (2020) stresses that the basic knowledge to operate both software and hardware tools is essential to bring maturity in the proper use of them in right time.

Similarly, Paudel (2020) argues that some of the schools in Nepal located in urban areas have run the online classes by using different digital apps where there is the Internet facility and parents are capable enough to manage basic technologies for online classes. Have you taken any training about the proper use of ICT tools to participate in online class?, in response of this question, Asha replies: 
No, I haven't taken any training to use ICT tools. But . . I think, for simple use, we can learn ourselves if we want to learn. The most important matter is tool. If we have any ICT tool, certainly we learn gradually ... from our friends as well. We can learn the use of different learning tools from internet too.

As Asha replied, availability of learning tool is important. When we have the tool, we can learn how it is operated. We can learn from our close friends who know more about the use of any kinds of ICT tools. Sapkota (2020) focuses on the best use of available resources by engaging students and teachers in micromanagement of technological tools. From this, it is obvious that we can use our mobile, laptop, desktop computer which is available at our home.

In the response of same question, Tank reacts:

Do you know normal literate people can use mobile phone easily in Nepal? I see everyone has an android mobile. They watch YouTube videos in it. Certainly, in my opinion, common sense is sufficient to use the normal tools of ICT. I am aware about the proper use because I am a learner. So, for learning, I must do the best from my side using mobile phone.

Tank also seemed aware and sincere in the use of ICT tools which are available common tools to enhance online learning. By utilizing mobile phone, he conducted online learning smoothly. Answering one of the researcher's questions, Rajanish (shaking his head) opines:

Yes, of course. I have taken training of basic computer class. I learned much more about the apps used in computer. So I bought Wi Fi service. We must be aware about the use of technology. I think I am technologically aware. We are in the 21st century, you know, this is the era of technology.

It reveals that Rajanish has got the training on the use of ICT. So, he connected Wi Fi at his home and learnt from online class regularly. Chaudhary (2020) focuses on the use of digital resources for present and future development of learning process. Online learning seems essential in this 21 st era of technology. But, Dawadi, Giri and Simkhada (2020) argue that there exists a huge challenge to give equitable access to e-learning to all the students in Nepal and a swift move to e-learning will further widen the disparity gaps, depriving a large number of students from inclusion. In the case of school level, it is right in larger extent, but it is not a suitable view in the case of higher education. 


\section{Online class as home delivery class}

Without active participation of the students, online class has no meaning. Besides physical class in semester system, the online class learning activities are also student centered where students' active participation is considered important in various activities such as presentation, answering questions, etc. In response of the question, 'why do you think online learning is significant in the context of Nepal?

Tank (shaking his both hands) opines:

I think it is not necessary to establish campuses and colleges in each and every village of the country. To develop physical infrastructure, high amount of money is required and it also takes a long period of time. Many students are deprived from higher education in Nepal. If stakeholders pay attention to online class, adult learners of different remote parts of the country can learn in university level through it.

Tank has not denied the importance of physical class in the normal situation. However, he emphasized on online class learning and drew the attention of concerned stakeholders. According to Kebritchi, Lipschuetz and Santiague (2017, p. 4) "Online education changes all components of teaching and learning in higher education." Online class facilitates the learning of university students. Kim and Bonk (2006) state that institutions emphasize collaborative learning and project based learning through online instructions.

Rajanish forwards his view as "online learning seems to be the significant for higher education in Nepal. Students are conscious in higher level. But in lower level, it is not beneficial." Due to matured mind, students of university class certainly get benefit from online learning by using the Internet service as Bakia, Shear, and Toyama (2012) contend that online learning as Internet-based teaching and learning.

Focusing on women empowerment in the context of Nepal, Asha states:

Online class seems significant in our country where many females are out from higher education. In my opinion, online class can be developed as home delivery class, it will certainly be significant. As I see the compulsory attendance in semester system.

As Asha replied, online class can be significant for female adult learners in Nepalese context. Online learning seems paramount important for women 
empowerment by creating opportunity of online education. Chapagain (2020) concurs that academic achievement of a child in Nepal is mostly based on theoretical knowledge. When teaching and learning activities for school level children are conducted through online class, they could gain practical knowledge by participating actively in the learning process.

Poudel (2020) argues that post-corona era can neither be the era of the death of physical classrooms nor an era of revolution in online classrooms. Though learning from online class has become mandatory at the time of pandemic, it will never replace the learning by attending the physical classroom setting. However, in the case of higher study, online classes seem significant in the context of Nepal which can be maximized in upcoming days.

\section{Conclusion}

Online class can be taken as an innovative class. It is considered as the best means to regulate teaching and learning in COVID-19 like crisis. To meet the objectives of the study from the analyses of collected data, the results of this study show that online classes are significant to continue the learning process of semester system in the context of Nepal. Personal endeavours can be essential to learn through online classes. Through online learning, the semester students of master's level can highly be benefitted in this 21 st century in particular. School level students' perceptions about online learning in Nepalese context could be the possible area of further investigation.

\section{References}

Agarwal, S. \& Kaushik, J. S. (2020). Student's perception of online learning during COVID pandemic. The Indian journal of pediatrics. 87(7):554. Retrieved from: https://doi.org/10.1007/s12098-020-03327-7

Ali,W. (2020). Online and remote learning in higher education institutes: A necessity in light of COVID-19 pandemic. Higher education studies, 10 (3). Retrieved from: https://doi. org/10.5539/hes.v10n3p16

Bakia, M., Shear, L., Toyama, Y., \& Lasseter, A. (2012). Understanding the implications of online learning for educational productivity. Center for technology in learning SRI international, U.S. Department of Education

Chapagain, B. S. (2020, July). Significance of parents' involvement in children's learning in crisis and ever. Retrieved from: http://eltchoutari.com/2020/07/ significance-of-parentsinvolvement-in-childrens-learning-in-crisis-and-ever/ 
Chaudhary, P. (2020, April 20). Perceptions on digital literacies and implementation practices: Perspectives of English teachers. Retrieved from: http://eltchoutari. com/2020/04/perceptions-on-digital-literacies-and-implementationpracticesperspectives-of-english-teachers/

Cojocariu, V.-M., Lazar, I., Nedeff, V., \& Lazar, G. (2014). SWOT analysis of e-learning educational services from the perspective of their beneficiaries. Procedia-social and behavioral sciences, 116, 1999-2003.

Dawadi, S., Giri, R. A., \& Simkhada, P. (2020). Impact of COVID-19 on the education sector in Nepal: Challenges and coping strategies. Sage submissions. Preprint. doi: https://doi.org/10.31124/advance.12344336.v1

Dhami, B. S. (2020, April 20). Lockdown, physical distancing and isolation in Ramayana: An overview. [blog post]. Retrieved from: http:/eltchoutari. com/2020/04/ lockdown-physical-distancing-and-isolation-in-ramayana-anoverview/

Dhawan, S. (2020). Online learning: A panacea in the time of COVID-19 crisis. Journal of Educational Technology Systems, 49(1), 5-22. doi: $10.1177 / 0047239520934018$.

Jena, P. K. (2020). Online learning during lockdown period for covid-19 in India. International Journal of Multidisciplinary Educational Research (IJMER), Vol 9. 5(8). 82-92.

Kabir, S.M.A. (2020). Issues and possible options for teachers: A COVID-19 pandemic perspective. http://eltchoutari.com/2020/07/issues-and-possibleoptions-for-teachersa-covid-19-pandemic-perspective/

Kapar, H. (2020, July). Online class amidst COVID-19 lockdown. http://eltchoutari. com/2020/07/online-class-amidst-covid-19-lockdown/

Kebritchi, M., Lipschuetz, A. \& Lilia Santiague, L. (2017). Issues and challenges for teaching successful online courses in higher education: A literature review. Journal of educational technology systems, 46(1), 4-29. DOI: $10.1177 / 0047239516661713$

Kim, K. J., \& Bonk, C. J. (2006). The future of online teaching and learning in higher education: The survey says. Educause quarterly, 4, 22-30.

Le Van, T. (2020). Techniques of online teaching. Retrieved from: http://eltchoutari. com/2020/07/ techniques-of-online-teaching/

Littlefield, J. (2018). The difference between synchronous and asynchronous distance learning. Retrieved from: https://www.thoughtco.com/synchronous-distancelearningasynchronousdistance-learning-1097959

Ministry of Education (2013). ICT master plan 2013-2017. Kathmandu: MOE. 
Ministry of Education (2016). School sector development plan 2016-2023. Kathmandu: MOE.

Ministry of Education Science and Technology (2020). Student learning supportive directive (in Nepali). Kathmandu: MOEST

Ministry of Education Science and Technology. (2020). Alternative learning system implementation guidelines. Retrieved from: https://moe.gov.np/article/1323/ $\mathrm{html}$

Ministry of Information and Communication (2015). National information and communication technology policy. Kathmandu: MOIC.

Mishra , L. Gupta, T. \& Shree, A. (2020). Online teaching-learning in higher education during lockdown period of COVID-19 pandemic. International journal of educational research. doi: https://doi.org/10.1016/j. ijedro.2020.100012

National Curriculum Framework 2006. Kathmandu: Curriculum Development Centre.

National Curriculum Framework 2019. Kathmandu: Curriculum Development Centre.

Nepal, K. (2020, July). Empowering learners with learning strategies: Preparation for uncertainties. Retrieved from: http:/eltchoutari.com/2020/07/empoweringlearners-with-learningstrategies-preparation-for-uncertainties/

Pal, D. \& Vanijja, V. (2020). Perceived usability evaluation of Microsoft Teams as an online learning platform during COVID-19 using system usability scale and technology acceptance model in India. Children and youth services review, 119, 105535. https:// doi.org/10.1016/j.childyouth.2020.105535

Parajuli, K. (2020, July). Expectations of post-COVID-19 era education in Nepal. http:// eltchoutari.com/2020/07/expectations-of-post-covid-19-era-educationin-nepal/

Paudel, P. R. (2020, July). Crisis, teaching-learning via alternative means and ground reality. http://eltchoutari.com/2020/07/crisis-teaching-learning-viaalternative-meansand-ground-reality/

Phyak, P., Sapkota, B., Acharya, R., \& Shrestha, D. K. (2020, July). Teacher agency in a superdifficult circumstance: Lessons from a low-resource context during COVID19. http://eltchoutari.com/2020/07/teacher-agency-in-a-superdifficultcircumstancelessons-from-a-low-resource-context-during-covid-19/

Poudel, P. (2020, July). Transforming school education: Learning from COVID-19 
and pathways ahead. http://eltchoutari.com/2020/07/transforming-schooleducationlearning-from-covid-19-and-pathways-ahead/

Poudel, T. (2020, April 20). Teaching virtually in COVID-19 pandemic: A reflection of a university professor. [blog post]. Retrieved from: http://eltchoutari. com/2020/04/ teaching-virtually-during-the-covid-19-a-reflection-of-auniversity-professor-innepal/

Rana, K. (2020, April 20). E-learning is only a means but not a replacement of physical classroom [blog post]. Retrieved from: http://eltchoutari. com/2020/04/e-learning-isonly- a-means-but-not-a-replacement-of-physicalclassroom-dr-rana/

Rapanta, C., Botturi, L., Goodyear, P., Guàrdia, L \& Koole, M. (2020). Online university teaching during and after the COVID-19 crisis: Refocusing teacher presence and learning activity. Post digital science and education, 2, 923945. Retrieved from: https://doi.org10.1007/s42438-020-00155-y

Sapkota, A. (2020, April 20). Awareness of ICT tools: Micro-management and way forward. [blog post]. Retrieved from: http://eltchoutari.com/2020/04/ awareness-ofict-prepatory-tools-micro-management-and-way-forward/

Singh, V., \& Thurman, A. (2019). How many ways can we define online learning? A systematic literature review of definitions of online learning (1988-2018). American journal of distance education, 33(4), 289-306.

Thapa, M. (2020, July). Can distance learning be widely adopted at academic institutions?http://eltchoutari.com/2020/07/can-distance-learning-be-widelyadoptedat-academic-institutions/

\section{Appendix A}

\section{Interview guideline questions}

1. How do you perceive online class during COVID-19 crisis?

2. Why do you think online class is significant in the context of Nepal?

3. What are the requirements to take an online class?

4. Why do you think it should be promoted in Nepal?

5. Are students really benefitted from online class?

6. How do you take online class from your home?

7. What do you think about the continuation of online classes in Nepal?

8 . What's the condition of access of internet to run online class in your locality? 